\title{
Manuele Gragnolati
}

\section{Authorship and performance in Dante's Vita nova}

At first glance, Dante's Vita nova may seem a puzzling choice for exploring the concept of performance in the Middle Ages. While performance appears in many guises in medieval culture and offers interesting insights for investigating numerous medieval texts, it seems to be absent from Dante's libello and the Italian lyric tradition from which it stems. The most obvious type of performance that is absent in Dante's Vita nova is the tight union of music and text that is a salient characteristic of Occitan poetry and is related to its oral performance in front of a large, aristocratic audience in the court. Critics have not yet explained the exact role of music for Italian lyric poetry in the thirteenth century, but the separation between text and music in the Vita nova is not only suggested by the text's own self-representation as a written record of its author's memories, but also confirmed by the work's prosimetric structure, which organizes 31 poems, for the most part certainly written before, within a unitary prose narrative. ${ }^{1}$

Another typical feature of Occitan poetry, which is also related to its oral performance in the court and would seem to be absent in the Vita nova, may be called the performance of a 'social I' connected to the repetition and re-enforcement of the courtly conventions and ethos which the public would have recognized as its own. Whether or not this kind of performance continued to be a feature of Sicilian poetry, an individual voice asserts itself more strongly over the collective, social ' $\mathrm{T}$ ' as

1 The prose can be divided into 'ragioni', which describe the events that inspired the poems, and 'divisioni', which comment upon their structure. On the relationship between the Vita nova's prosimetric character and the separation between poetry and prose, 'che era stato sino ad allora soltanto possibile o probabile', see Claudio Giunta, Versi a un destinatario. Saggio sulla poesia italiana del Medioevo, Bologna 2002, pp. 386-387, who makes reference to Nino Pirrotta, Musica tra Medioevo e Rinascimento, Turin 1984; Poesia, musica e altri saggi, Florence 1994, pp. 1-21. For the meditative character that lyric poetry acquires in Italy, see Paul Oppenheimer, The Birth of the Modern Mind. Self, Consciousness, and the Invention of the Sonnet, Oxford 1989, pp. 1-40; and Michelangelo Picone, 'Traditional Genres and Poetic Innovation in Thirteenth-Century Italian Lyric Poetry', in Medieval Lyric: Genres in Historical Content, ed. by William Paden, Urbana, Chicago 2000, pp. 146-157. 
lyric poetry moves, after the death of Frederick in 1250, to Tuscany and Central Italy, first with the Tuscan poets and then with the Stilnovisti and especially the Vita nova. Indeed, by presenting itself as transcribing from the author's book of memory the story of how his love for Beatrice renewed his life, Dante's libello is autobiographical and its narrative refers to a specific, historical individual. ${ }^{2}$

If there is neither evidence of a literal performance situation-the author reciting or singing in front of a live audience-nor of the collective, generic 'I' that such a public performance produces, how can one think of performance in the case of the Vita nova? What I would like to propose is that as a more autobiographical content and subjective character replace the social function of Occitan poetry, the Vita nova deploys another kind of performance: not the performance of a social ' $\mathrm{T}$ ', but the 'performance of an author'.

A first aspect of this complex operation, which conveys several layers and aspects of performance, can be inferred by some essays written by Michelangelo Picone on the Vita nova. Picone explored the ways in which the text presents itself as discovering and reconstructing the past of the protagonist-actor as a spiritual and poetic development corresponding to his development towards becoming an auctor, that is, with Alistair Minnis's words, someone who is 'at once a writer and an authority, someone not merely to be read but also to be respected and believed'. ${ }^{3}$ In particular, Picone argues that unlike the Convivio, where Dante attempts to gain

2 On the individuality of the ' $\mathrm{I}$ ' in the Vita nova, no matter how partial when compared to contemporary notions, see Charmaine Lee, La soggettività nel Medioevo, Rome 1996, pp. 5-44; Peter Dronke, Verse with Prose from Petronius to Dante: The Art and Form of the Mixed Form, Cambridge, Mass. 1992, pp. 84-114, especially 107-114. Recently Giunta has proposed that in the late thirteenth century a subjectivization of love experience would take place that denotes a veritable shift in the Western lyric and culminates in Dante's libello, which would thereby represent the beginning of a 'poesia soggettiva ... qualitativamente non diversa da quella che oggi noi siamo abituati a leggere' (Versi a un destinatario, p. 428). In particular, Giunta distinguishes between 'un testo in cui il soggetto che parla non è il poeta $\mathrm{e}$ un testo in cui il soggetto che parla-per quanto camuffato, per quanto la sua voce ci giunga filtrata da luoghi comuni-è il poeta... [L]a prima forma di lirica si avvicina al teatro, perché mette in scena personaggi ed eventi fittizi ed esemplari. La seconda si accosta, invece, [...] all'autobiografia' (pp. 384-385). See also Olivia Holmes, Assembling the Lyric Self: Authorship from Troubadour Song to Italian Poetry Book, Minneapolis 2000.

3 The definition of auctor is given by Alistair J. Minnis, Medieval theory of authorship. Scholastic literary attitudes in the later Middle Ages, Aldershot 1988, p. 10. For Michelangelo Picone's essays, see 'Strutture poetiche e strutture prosastiche nella Vita Nuova', in MLN 92 (1977), pp. 117-129; 'La Vita Nuova tra autobiografia e tipologia' in Dante e le forme dell'allegoresi, ed. by Michelangelo Picone, Ravenna 1987, pp. 59-69; 'La teoria dell' Auctoritas nella Vita nova', in Tenzone 6 (2005), 173-191. 
authority by placing emphasis on the encyclopaedic nature of his work, ${ }^{4}$ the Vita nova's strategy to grant authority to itself consists of applying to its own poems the exegetical practices that were at first applied to reading and commenting the Sacred Scriptures and then were also used for the texts of classical auctores. ${ }^{5}$

Picone, who bases his analysis upon Minnis's scholarship on medieval authorship ${ }^{6}$ and develops further some insights by Charles Singleton, ${ }^{7}$ focuses on the initial paragraph of the Vita nova, where Dante indicates his modus operandi for writing the the libello:

In quella parte del libro de la mia memoria dinanzi a la quale poco si potrebbe leggere, si trova una rubrica la quale dice: Incipit vita nova. Sotto la quale rubrica io trovo scritte le parole le quali è mio intendimento d'assemplare in questo libello, e se non tutte, almeno la loro sentenzia (I.1 [1.1]). ${ }^{8}$

In that part of my book of memory before which there would be little to read is found a charter heading which says: 'Here begins a new life'. It is my intention to copy into this little book the words I find written under that heading-if not all of them, at least their significance.

Picone shows that the authorial figure of Vita nova presents his activity as interpreter of his own past through a series of different and progressive

4 For a different reading, which highlights instead the influence played by medieval commentaries on the Song of Songs, see Zygmunt Baranski, 'Il Convivio e la poesia: problemi di definizione', in Contesti della 'Commedia'. Lectura Dantis Fridericiana 2002-2003, ed. by Francesco Tateo, Daniele M. Pegorari, Bari 2004, pp. 9-64.

5 'La teoria dell' Auctoritas nella Vita nova'. On Dante's assumption of authority in Vita nova, Convivio and De vulgari eloquentia, and on the evolution of the concept of 'authorship' in Dante's oeuvre, see the recent book by Albert R. Ascoli, Dante and the Making of a Modern Author, Cambridge 2008, as well as three previous articles by Ascoli: 'From auctor to author: Dante before the Commedia', in The Cambridge Companion to Dante, ed. by Rachel Jacoff, Cambridge 2007, 2nd edn, pp. 46-66; 'The Vowels of Authority (Dante's Convivio IV, vi, 34)', in Discourses of Authority in Medieval and Renaissance Literature, ed. by Kevin Broownlee, Walter Stephens, Hanover, NH 1989, pp. 23-46; “'Neminem ante nos”: Historicity and Authority in the De vulgari eloquentiae', in Annali d'italianistica 8 (1990), pp. 186-231. See also Thomas C. Stillinger, The Song of Troilus. Lyric Authority in the Medieval Book, Philadelphia 1992, pp. 44-117; Zygmunt Baranski, 'Dante Alighieri: Experimentation and (Self)Exegesis', in The Cambridge History of Literary Criticism, ed. by Alastair Minnis, vol. 2, Cambridge 2005, pp. 561-82.

6 Minnis, Medieval Theory of Authorship. See also Medieval Literary Theory and Criticism c. 1100 c.1375. The Commentary Tradition, ed. by A.J. Minnis, A.B. Scott, Oxford 1988, pp. 373-394.

7 Charles Singleton, An Essay on the Vita Nuova, Cambridge, Mass. 1986, pp. 25-54.

8 I quote Dante's libello from Dante Alighieri, Vita Nuova, ed. by Domenico De Robertis, Milan, Naples 1980, which uses the text by Michele Barbi (Dante Alighieri, Vita Nuova, Florence 1932). The indication of the text according to its traditional subdivision into forty-two chapters is followed by its indication according to the subdivision into thirtyone paragraphs proposed by Gugliemo Gorni (Dante Alighieri, Vita Nova, ed by. Guglielmo Gorni, Turin 1996). Translations from the Vita nova are taken from Dante, Vita Nuova, trans. by Mark Musa, Oxford 1992. 
operations: 1) that of a scriptor, the copyist transcribing from his own book of memory the poems written to celebrate his love for Beatrice as well as the memories connected with writing these poems; 2) that of a compilator, who does not only copy the poems and the memories connected with them, but also selects them and organizes them according to a meaningful, teleological order; and 3) that of a commentator, who comments upon his poems and memories and not only confirms the literal meaning carried by the words transcribed but also reveals the allegorical one: 'sentenzia' in the last quotation indicates the 'significance', that is, the ultimate and definitive meaning ('il ... significato ultimo e definitivo') of the narrated poems and memories - a meaning that was not necessarily evident when the poems were originally written or the events took place but that would now be authorized by the heavenly vision described in the last sonnet, where Dante's 'spirit' goes to Heaven and contemplates Beatrice. ${ }^{9}$

As a result of these operations, which are presented as the means to discover and convey the real meaning of the past events, an auctor asserts himself who has not only obtained the same artistic value as the classical authors but who also can indicate his own trajectory as a lover as an example for the other poets forming the public to which the text is addressed. The Vita nova can thus be seen as a performance both in the sense that it is performed by an auctor and in the sense of a Selbstinszenierung, a mise en scène of the author's own development in his poems in conformity with an ideal development from uncertain and wrong beginnings to the discovery of a correct way of loving and writing about it.

This Selbstinszenierung is an important aspect of the author's performance in the Vita nova, but I would like to suggest that the Vita nova performs the author also in a stronger, performative sense that goes beyond discovering, re-constructing, and re-presenting the author's journey according to an ideal pattern, and involves rather the creation of an author through language. Making an analogy with John Austin's original distinction between constative and performative utterances - that is, between utterances simply describing something and utterances 'doing' something, between utterances affirming facts and utterances producing them -, and referring to Jonathan Culler's discussion of the performative character of literature and the 'active, creative functioning of language', one could indeed say that in my reading, the Vita nova's operation is not constative but, rather, performative, and must therefore be judged not

9 'La teoria dell' $A$ uctoritas nella Vita nova', pp. 177-181 and Michelangelo Picone, 'Leggere la Commedia di Dante', in Lectura Dantis Turicensis, ed. by Georges Güntert, Michelangelo Picone, vol. 1: Inferno, Florence 2000, pp. 13-25 (quotation on p. 16). 
from the perspective of its truth but of its success: ${ }^{10}$ Dante's libello does not discover or describe the true meaning of the poems originally written as free-standing rime, but rather creates new poems which did not exist before and now exist alongside the originals. In particular, I am interested in how an author comes into being as the poems that Dante had originally written as independent and free-standing rime are staged in the Vita nova through the operations of selection, order and commentary. That is, my perspective is not on how these operations participate in the discovery of an ideal meaning for Dante's poetic past but, rather, on how they create a new author, who is different from the one of the past.

My collaboration with Teodolinda Barolini on an edition of Dante's Rime has proved very important for elaborating this critical perspective. ${ }^{11}$ Something that Barolini highlights in her introductions to the individual poems and that has struck me while writing the commentaries in the footnotes for them is what different texts one often encounters when reading them as free-standing rime or as a part of the Vita nova. Some of the differences between the poems as rime and as part of the Vita nova have already been pointed out by Domenico De Robertis in his volume Il Libro della Vita Nuova (1961 and then 1970) and in his 1980 commented edition of the Vita nova, where De Robertis has also indicated that some textual variants were introduced into some poems when they were placed into the Vita nova. ${ }^{12}$ Yet, although some very important contributions have indicated the models for the libello's prosimetric nature, the temporallydouble perspective characterizing the Vita nova's operation has not been

10 John L. Austin, How to Do Things with Words: The William James Lectures delivered at Harvard University in 1955, ed. by J. O. Urmson, Oxford 1962. For a discussion of Austin's theory and its significance for literary and cultural criticism, see Jonathan Culler, 'Philosophy and Literature: The Fortunes of the Performative', in Poetics Today 21 (2000), pp. 503-519; quote on p. 506. For a discussion of Austin's role in contemporary performance theory, see Uwe Wirth, 'Der Performazbegriff im Spannungsfeld von Illokution, Iteration und Indexikalität', in Performan₹. Von Sprachphilosophie zu den Kulturwissenschaften, ed. by Uwe Wirth, Frankfurt a. M. 2002, pp. 9-53; and Erika Fischer-Lichte, Ästhetik des Performativen, Frankfurt a. M. 2004, pp. 31-57.

11 Dante Alighieri, Rime giovanili e della 'Vita Nuova', ed. by Teodolinda Barolini; with notes by Manuele Gragnolati, Milan 2009. The volume contains sixty-two poems (fifty-seven by Dante Alighieri and five by Dante da Maiano). See also Teodolinda Barolini, 'Saggio di un nuovo commento alle Rime di Dante. 1. La dispietata mente che pur mira: l'io al crocevia di memoria e disio; 2. Sonar bracchetti e cacciatori aizzare: l'io diviso tra mondo maschile e mondo femminile; 3. Guido, i' vorrei che tu e Lippo ed io: l'io e l'incanto della non-differenza', in Dante: Rivista internazionale di studi danteschi 1 (2004), pp. 21-38.

12 Domenico De Robertis Il libro della 'Vita Nuova', 2nd edn, Florence 1970; Dante, Vita Nuova, ed. by De Robertis. These variants have now been systematized and often commented upon in the latest editions of Dante's rime edited by De Robertis: Dante Alighieri, Rime, ed. by Domenico De Robertis, 3 vols., Florence 2002; Dante, Rime, ed. by De Robertis, Florence 2005. 
the object of major attention by critics, who seem to have devoted their analysis to exploring the 'sententia', the 'significance', presented in the Vita nova, that is, to analyze the meaning that the poems have within the libello and that is presented as the true one finally discovered and outlined. ${ }^{13}$ In an article on Dante's rime, for instance, Picone stresses that the poems have a different meaning whether read independently or in the Vita nova, ${ }^{14}$ but claims that once a rima has been introduced in the Vita

13 As Teodolinda Barolini recently pointed out, 'the divergence between the prose and the poems is striking and understudied' ('Editing Dante's Rime and Italian Cultural History: Dante, Boccaccio, Petrarca ... Barbi, Contini, Foster-Boyde, De Robertis', in Lettere italiane 56 [2004], pp. 409-442; then in Teodolinda Barolini, Dante and the Origins of Italian Literary Culture, New York 2006, pp. 245-278 and 433-441, from which I quote; the quotation is on p. 439). A similar point had already been made by Mario Marti, "L'una appresso de l'altra maraviglia" (V.N., XXIV, 8): Stilnovo, Guido, Dante nell'ipostasi vitanovistica', in La gloriosa donna de la mente, ed. by Vincent Moleta, Florence 1994, p. 152: 'È singolarmente strano e mi è difficilmente comprensibile il fatto che gli studiosi di Dante sappiano bene come sono andate le cose circa la intellettualistica 'costruzione' della Vita Nuova da parte dell'autore pressoché al di là del giovanile Stil nuovo [...], e poi all'atto pratico considerino l'opera come se invece fosse nata di getto, tutta d'un pezzo, senza far conto alcuno della sua peculiare genesi e della sua interna storia editoriale, e quindi del senso originario dei testi poetici, piegati vistosamente da Dante alle nuove e diverse conclusioni e magari ai nuovi proponimenti progressivamente insorti, chiariti e formulati'. Also Stefano Carrai indicates that 'l'interazione tra le due componenti del testo è un aspetto di primaria importanza per comprenderne il significato. Eppure esso non sembra avere attratto granché l'attenzione degli studiosi. Pochi in effetti sono i lavori specifici che si registrano sulla complementarità fra prosa e poesie e sulla loro diversa funzionalizzazione' (Dante elegiaco. Una chiave di lettura per la 'Vita nova', Florence 2006, p. 77). However, Carrai focuses mainly on the harmony between prose and poetry (especially in the context of the elegiac narrative and mode), and even when he claims he does not want to fall into Dante's trap, he largely believes that some poems may have been written especially for the Vita nova. In addition to the works mentioned by Carrai (Ignazio Baldelli, 'Sul rapporto fra prosa e poesia nella Vita Nuova', in Rassegna della letteratura italiana s. VIII, 80 [1976], pp. 325-337; Picone, 'Strutture poetiche e strutture prosastiche'; 'La Vita nova come prosimetrum', in Percorsi della lirica duecentesca. Dai Siciliani alla 'Vita nova', Florence 2003, pp. 237-248; Giorgio Petrocchi, 'Il prosimetrum nella Vita Nuova, in La selva del protonotario. Nuovi studi danteschi, Naples 1988, pp. 17-31), a significant exception is represented, from my perspective, by two essays by Roberto Leporatti, 'Ipotesi sulla Vita Nuova (con una postilla sul Convivio)', in Studi italiani 7 (1992), pp. 5-36; "'Io spero di dicer di lei quello che mai non fue detto d'alcuna" (V.N., XLII, 2): la Vita Nuova come retractatio della poesia giovanile di Dante in funzione della Commedia', in La gloriosa donna de la mente, pp. 249-291. See also Justin Steinberg's discussion regarding the shift of the canzone Donne ch'avete intelletto d'amore from free-standing rima to part of the Vita nova (Accounting for Dante. Urban Readers and Writers in Late Medieval Italy, Notre Dame 2007, pp. 61-92). I have also found helpful Stillinger, The Song of Troilus, pp. 1-22 and 44-117; Steven Botterill, "Però che la divisione non si fa se non per aprire la sentenzia de la cosa divisa" (V.N., XIV, 13): the Vita Nuova as commentary', in La gloriosa donna de la mente, pp. 61-76.

14 'Ha ... ragione Barbi nel ritenere essenzialmente diversa una lirica letta nel contesto della Vita Nuova o del Convivio dalla stessa lirica letta invece singolarmente. Una rima accompagnata o meno dal commento dell'autore non viene insomma recepita allo stesso 
nova or the Convivio, it acquires its proper meaning: 'Ritengo infatti che una lirica, una volta che è stata inclusa nella Vita nuova o nel Convivio, ha perduto il suo carattere di prova estemporanea, per entrare a far parte di una totalità letteraria e di un ingranaggio compositivo dai quali soltanto riceve il suo significato' (174). On this assumption, Picone draws the conclusion that the lyrics included in the Vita nova or the Convivio lose their status as rime and should therefore not be published among the rime. In an article on the theoretical principles informing the editions of Dante's rime from Barbi's to De Robertis's, Barolini discusses Picone's argument in some detail, showing the tensions between his view that 'the Vita nova and Convivio poems deserve their own space within the lyric tradition' and his conclusion that they should not be included in an edition of Dante's rime. Barolini argues that this conclusion is conditioned not only by the 'need to respect Dante's will as the auctor of the Vita Nova', but also by Petrarch's eventual decision to transcribe his poems in a unified and organic book. Barolini objects that in this way 'a lyric tradition in which no stigma attaches to the free and uncollected lyric is viewed through an inappropriate lens that describes it in terms of what it is not'. ${ }^{15}$ She therefore includes every lyric poem written by Dante in her edition of the rime, and her commentary maps the history of 'how Dante became Dante', tracing Dante's intellectual development as well as the connections between his lyric poems and the Commedia.

By exploring the Vita nova from a performative perspective, the question of the rime's true meaning becomes secondary to the question of how the Vita nova succeeds in creating new meanings that are so compelling that they can appear to erase any previous meaning. As I mentioned before, textual variants are sometimes introduced in the original poems at the moment of their insertion into the Vita nova, but often it is the mise-en-scène of the poems in the Vita nova that effectively re-writes the poems, endowing them with a new meaning that they did not originally have. While there is no relation of truth between the old and the new poems (in the sense that a poem, once inserted in the Vita nova, becomes a new poem and it is not that one is truer than the other), the critics' claim that, once inserted in the Vita nova, a poem loses its status as rima attests to the success of the Vita nova's performance. What my following analysis will attempt to explore is how this success works, that is, how the Vita nova succeeds in creating new meanings and presenting them as the 'true' meanings of the original lyrics.

modo dal lettore' ('Dante rimatore', in Letture classensi 24 [1995], pp. 171-188; quotation on p. 174).

'Editing Dante's Rime', p. 268. 
The transformations and the new meanings that the lyric poems acquire in the Vita nova are many, but in this paper I will focus on the episodes staging the author's spiritual and poetic journey with respect to the figure of Guido Cavalcanti. It will thus be possible to appreciate the ambivalent way in which the Vita nova can be defined as an 'act of independence': on the one hand, the Vita nova is addressed, if not dedicated to, Cavalcanti, refers to him as an authoritative poet and presents him as Dante's 'first friend', who introduced him to poetry and helped him to affirm himself as a poet; but, on the other hand, the Vita nova re-presents the past of its author as a progressive and ideal ability to distance himself form the wrong way of writing à la Cavalcanti that had been a significant part of his poetic and spiritual apprenticeship, and to find a new, correct way of loving and writing about it. ${ }^{16}$ In particular, it is in the Vita nova that some of the perspectives begin to emerge that will structure the more mature and complex way in which the Commedia stages the relationship of its author with Cavalcanti, such as the philosophical competence of Guido, the relationship between love and reason, and Beatrice's similarity to Christ. But it will be especially possible to appreciate the way in which, through the operations of selection, order and commentary, a new author emerges in the Vita nova who is different—often substantially different—from the one who had written the rime.

The first sonnet of the libello already represents a good example of how in the Vita nova previously written poems become new poems.

16 The phrase 'act of independence' is taken from Robert Harrison, The Body of Beatrice, Baltimore 1988, p. 84. See also Teodolinda Barolini, Dante's Poets: Textuality and Truth in the 'Comedy', Princeton 1984, pp. 123-153, especially 136-138. After the publication of Enrico Malato, Dante e Guido Cavalcanti: il dissidio per la 'Vita Nuova' e il disdegno di Guido, Rome 1997 (2nd edn 2004), a harsh debate originated about the temporal relationship between Dante's Vita nova and Cavalcanti great philosophical canzone Donna me prega. This question does not concern my analysis directly, but I would like to stress that there is no 'objective' element that allows us to maintain the antecedence of either text; see Teodolinda Barolini, 'Dante and Cavalcanti (On Making Distinctions in Matters of Love): Inferno 5 in its Lyric Context', in Dante Studies 116 (1998), pp. 60-63; and Giorgio Inglese, 'Per Guido Cavalcanti', in L'intelletto e l'amore. Studi sulla letteratura italiana del Due e Trecento, Florence 2000, pp. 12-52; Mario Marti, 'Da "Donna me prega" a "Donne ch'avete": non viceversa', in Da Dante a Croce: proposte consensi dissensi, Galatina 2005, pp. 7-15. I would tend to believe that the Vita nova follows Donna me prega, and I wonder whether many of the re-writings that, as we shall see, have been performed in the Vita nova are actually to be understood as a reply to Guido's doctrinal canzone. For an updated bibliography on the relationship between Dante and Guido, see Zygmunt Baranski, "Per similitudine di abito scientifico": Dante, Cavalcanti and the Sources of Medieval 'Philosophical' Poetry', in Literature and Science in Italian Culture: From Dante to the Present Day, ed. by Pierpaolo Antonello, Simon Gilson, Oxford 2004, pp. 44-45, n. 21. 
Originally, A ciascun'alma presa e gentil core is a mere poetic riddle similar to Dante da Maiano's Provedi, saggio, ad esta visione, to which the very young Dante replied with Savete giudicar vostra ragione. As a free-standing rima, $A$ ciascun'alma presa e gentil core offers an obscure description of a dream, which was sent to other poets, some of whom are 'famosi trovatori', famous poets (including Guido Cavalcanti and Dante da Maiano), so that they can decipher its opaque meaning. Through this envoy, the young Dante wanted to establish a dialogue and a relationship with other fellow poets. This aim was achieved, and we have three extant replies to the sonnet. Of these replies the libello mentions only that by Guido Cavalcanti, $V$ edeste a mio parere onne valore, indicating that this poetic exchange was the beginning of the friendship between the two poets.

The Vita nova changes the meaning of Dante's sonnet, which becomes the account of a vision prophesizing Beatrice's ascent to heaven, which the poet had after the second meeting with her at the age of eighteen. There is nothing in the sonnet itself that indicates that the lady held by Love in the vision is Beatrice, and it is only in the libello, which is centred on Beatrice's death and opens and closes with the image of her glory in heaven, that the dream described in the sonnet can represent a premonition of the lady's death. The creation of this new meaning is achieved by two details added in the Vita nova: while the sonnet ends with image of Love's departure ('appresso gir lo ne vedea piangendo'), the prose not only specifies that Love leaves still keeping her in his arms ('con essa'), but also adds that he goes to heaven ('verso lo cielo') - a detail that would otherwise be absent in the sonnet. This addition is noted by commentators, who generally interpret it as an anticipation of Beatrice's death. With Picone, I would rather think that, as lines 9-11 of Cavalcanti's reply had already mentioned the hypothesis that the dream may refer to Beatrice's death, in the Vita nova the dream is actually not a premonition of Beatrice's death but of her glorious destiny in heaven. ${ }^{17}$

While Picone stresses that this detail also refers to the glorious destiny of Beatrice's poet and to the fact that in the course of the Vita nova he will able to turn eros into caritas, I am rather interested in pointing out that in the Vita nova the meaning of the sonnet changes: while originally the sonnet was an 'open' riddle, in the Vita nova it acquires a definitive and evident meaning. The Vita nova settles the case, indicates the meaning that the poem really had, and adds that the true meaning ('verace giudizio') of the dream was not understood by anybody but is now evident even to the most simple people: 'non fue veduto allora per alcuno, ma ora è

17 'La Vita nova come romanzo', in Percorsi della lirica duecentesca, p. 254. 
manifestissimo a li più semplici' (III 15 [2.2]). Usually commentators indicate that the dream's true meaning is revealed by Beatrice's death, but I would rather say that this meaning is created by the way in which this sonnet is placed and commented upon in the Vita nova. In other words, as it is unlikely that this sonnet referred originally to Beatrice, ${ }^{18}$ it is not Beatrice's death that allows the author and everybody to understand what it really meant. On the contrary, the sonnet's new meaning is a textual performance of the Vita nova, which relates the text to Beatrice for the first time, inserts it in a context centred on her glorious destiny, and adds some significant details. This performance is so successful that after it has taken place, it is difficult to go back and see the open meaning that the poem had as a free-standing rima and that does not refer either to the lady's death or even to Beatrice.

While $A$ ciascun'alma presa was originally written by Dante as a bravura piece and circulated among poets to create a friendship and a dialogue with them, in the Vita nova it has a different aim and becomes a text endowed with a providential meaning conferring authority to its author. Moreover, as we have seen, it explicitly states that Guido Cavalcanti is one of the poets who did not succeed in understanding that which is now indicated as the true meaning of the poem. In this way, exactly at the moment when the Vita nova describes its author's entrance into the party of the 'Fedeli d'Amore' and attests to his official acceptance through the indication of his friendship with Cavalcanti, it is also possible to detect a first instance of the critique that the Divine Comedy will level against Guido's interpretative faculties. ${ }^{19}$

The Vita nova's performative success continues with the episode of the so-called 'screen-ladies', where some previously-written poems become new poems dealing with the love that the protagonist pretends to feel for two ladies with the purpose of making them 'schermo de la veritade' ('a screen for the truth'; V 3 [2.8]) and thereby hiding and protecting his beloved's true identity. The author says that in order to make people even more convinced of his simulated love for the screenladies, he wrote 'certe cosette per rima' ('certain trifles for her in verse'), of which, though, he transcribed in the libello only those containing a clear praise for Beatrice (V 4 [2.9]). When read without the prose, the Vita nova's poems about the screen-ladies do not convey any of the meanings that they have in the libello. For instance, as a free-standing rima, the sonnet $O$ voi che per la via d'amor passate is a 'canto dell'abbandono' (De

18 See Dante's Lyric Poetry, ed. by Kenelm Foster, Patrick Boyde, vol. 2, Oxford 1967, p. 23.

19 See Zygmunt Baranski, 'Dante and His First Readers', in Guido Cavalcanti tra i suoi lettori, pp. 149-176; "“Per similitudine di abito scientifico", pp. 13-52. 
Robertis, Il libro, 56), a conventional lament for the loss of a love that was reason for happiness and joy, and it is only in the Vita nova that it becomes a text written to show the sorrow felt for the first screen-lady's departure to another town, and inserted in the libello because it also refers to Beatrice. ${ }^{20}$

With the second sonnet of the episode, Cavalcando l'altrier per un cammino, Dante begins to criticize Cavalcanti in a more substantial way. In particular, as Barolini shows in her introduction to the poem, Dante uses the Cavalcantian concept that love is so intense that it needs some mediation in order to denounce the traditional courtly values and in particular the strategy of 'simulato amore' (IX 6 [4.6]). What I would like to underline is that the context of the Vita nova makes Cavalcando l'altrier a different text, in this case radically different, from what it is as a freestanding rima. While in itself the sonnet is about falling in love with a new lady, the Vita nova says that it was written after the departure of the first screen-lady: as the protagonist travels in the area where she had gone, Love appears to him and tells him that now that she has moved away, he must find a new screen-lady in order to continue to cover Beatrice's identity (IX 5 [4.5]). In this way, a sonnet that, as a free-standing rima, describes love's fickleness and the inconstancy of desire, in the Vita nova becomes a text celebrating the protagonist's loyalty and fidelity to Beatrice. It is an audacious operation but the performance is successful, as is demonstrated by recent hypotheses claiming that the text was especially written for the Vita nova. ${ }^{21}$

A similar, successful operation also concerns Ballata i' voi che tu ritrovi Amore. As a free-standing rima, the poem is a conventional exercise in the Occitan genre of the escondig in which the poet-lover refutes the negative lies circulating about him, while in the Vita nova it is addressed to Beatrice and becomes a text written to tell her that he has never ceased loving her. As in the case of Cavalcando l'altrier, these new meanings are also meant to criticize Cavalcanti's idea that love's intensity needs mediation. For this critique, I refer the reader to Barolini's introduction. Here, what I would like to stress about the new meanings that the libello creates for the texts related to the screen-ladies, is that this performative operation is so successful that it has even created new texts in absentia: while the screenladies exist only within the linguistic and poetic operation of the Vita nova,

20 For a detailed analysis of this sonnet as well as the others for the screen ladies, see Manuele Gragnolati, 'Trasformazioni e assenze: la performance della Vita nova e le figure di Dante e Cavalcanti', in Dante the Lyrical and Ethical Poet, ed. by Zygmunt Baranski, Martin McLaughlin, Oxford 2010.

21 See for instance Carrai, Dante elegiaco, pp. 107-112. 
the indication that only some of the 'certe cosette per rima' were included in the libello has pushed critics to try to identify which rime not included in the libello were written for the first screen-lady and which for the second. In other words, given my interpretation that there are no poems originally written for any screen-lady, the Vita nova succeeds in giving new meanings not only to the poems it includes but also to those that it leaves out!

After the episode of the screen-ladies, the re-presentation of the protagonist's spiritual and poetic journey continues with the so-called episode of the gabbo, which takes place after Beatrice is offended by the intensity of the love that Dante shows towards the second screen-lady, and withholds his greeting from him. This episode, which lasts from chapter XIV (7) until the discovery of the 'matera nuova e più nobile che la passata' ('a new theme, one more lofty than the last') in chapter XVII (10), continues to reflect on the limitations of past lyric modes. In particular, the loss of Beatrice's greeting, which is not mentioned in any poem, becomes the motif around which the Vita nova exemplifies a wrong way of loving that is irrational, narcissistic, and based on the traditional idea of expecting something back from the lady. The libello cites here some old poems written in a clearly Cavalcantian manner and thereby makes an explicit association between this wrong way of loving and Cavalcanti's poetry. With respect to the poems as free-standing rime, it also adds, or at least it makes it explicit, that this way of loving is irrational and goes against the guidance of reason. ${ }^{22}$

22 This is clear, for instance, in Ciò che m'incontra nella mente more (XV [8]), which is openly written in a Cavalcantian style and describes the poet-lover's fainting in front of the lady. While the poem is centred around the motif that the lover does not follow Love's advice to flee from the lady's presence ('Fuggi, se 'l perir t'è noia' ['Run the other way if you far death'; 4]) but continues to desire to see her although she is the reason for his 'death', the prose recalls the motif introduced in II 9 (1.10) and IV 2 (2.4), and adds that, in giving his advice, Love is 'counselled by reason' ('consigliato da la ragione'; XV 8 [8.8]). In this way, the libello creates an opposition between one way of loving that is guided by reason and another, associated with Cavalcanti, that is not. The contrast between Cavalcanti's concept of love, which stresses the opposition between love and reason, and the Vita nova, which affirms the connection between them, is an important aspect usually noticed by critics (see, for instance, Natascia Tonelli, 'Fisiologia dell'amore doloroso in Cavalcanti e Dante', in Guido Cavalcanti laico, ed. by Rossend Arqués, Alessandria 2004, pp. 81-82). What I find interesting to point out is that the issue of reason, usually absent in the poems (with the exception of the simile in 1.4 of the sonnet Amore e 'l cor gentil sono una cosa), is created by the prose. Here begins the journey that will lead to the great meditations on desire in Inferno 5 (for which see Barolini, 'Dante and Cavalcanti', 31-63) and Purgatorio 16-18 (for which see Roberto Antonelli, 'Cavalcanti e Dante: Al di qua del Paradiso', in Dante: Da Firenze all'aldilà, ed. by Michelangelo Picone, Florence 2001, pp. 289-302, especially 295-296; Donatella Stocchi Perucchio, 'The Knot of Cavalcanti in the Commedia: A Few Threads', in Guido Cavalcanti tra i suoi lettori, pp. 213-240), and on the human soul in Purgatorio 25, where Statius's embryological theory enters into a polemic with that of Avveroes connected to Cavalcanti. I have dealt with the Scholastic debate informing Statius's embryology in 
Rather than being concerned with giving new meanings to old poems, the episode of the gabbo aims at both staging a Cavalcantian phase of its author that is retrospectively presented as wrong and corrected in the following discovery of the 'stilo della loda', and at constructing the figure of Cavalcanti as a poet uniquely 'doloroso', narcissist and irrational. Thus, the 'stilo della loda', which consists in placing one's happiness not in the lady's greeting (as before) but in praising the lady's beauty and virtue without expecting any reciprocation back from her, can appear as a departure from Cavalcanti more than it has actually been. ${ }^{23}$

The author's ideal journey towards finding his own voice and distancing himself from Cavalcanti reaches its first culmination with the analogy that chapter XXV (15) creates between Beatrice and Christ and that is carefully prepared and made possible by what the libello stages before and after that chapter. On the one hand, Dante does not include in the Vita nova some poems previously written that would disrupt the ideal journey portrayed in the libello, such as the sonnet Ne le man vostre, gentil donna mia - where the poet is compared to the suffering Christ in a way that recalls Cavalcanti's tragic concept of love-or the canzoni Lo doloroso amor and E' m'incresce-where Beatrice's miraculous character is combined with a lethal and mortal power that also recalls Cavalcanti's poetry. ${ }^{24} \mathrm{On}$ the other hand, the Vita nova continuously creates a connectionotherwise absent in the poems-between Beatrice and the number 9, which is explicitly linked to the Trinity. ${ }^{25}$ Moreover, the libello amplifies Beatrice's miraculous and beneficial effects, thereby turning the beloved from a 'donna angelicata' similar to the ones of other Stilnovo texts into an almost divine being similar to Christ.

An interesting instance of such a transformation is represented by $\mathrm{Ne}$ li occhi porta la mia donna amore (XXI 2-4 [12.2-4]). This sonnet, which recalls several images from Guinizzelli's poetry and shares the metrical

Experiencing the Afterlife. Soul and Body in Dante and Medieval Culture, Notre Dame 2005, pp. 53-76. The presence of Cavalcanti's Donna me prega as a polemic intertext of Purgatorio 25 has recently been shown by Baranski, "'Per similitudine di abito scientifico”, pp. 29-36

23 See Leporatti, 'Ipotesi sulla Vita Nuova', p. 14.

24 For instance, in Lo doloroso amor, Dante writes 'Per quella moro c'ha nome Beatrice' (14), 'Through her I die, whose name is Beatrice'-a sentence that could not enter the Vita nova, where Beatrice brings life, not death. On Lo doloroso amor and E' m'incresce, discussed at length by Barolini in her edition of Dante's Rime, pp. 267-279 and 285-291, see also her observations in 'Dante and the Lyric Past', in The Cambridge Companion to Dante, pp. 27-28; and in 'Editing Dante's Rime', pp. 270-271.

25 See Robert Harrison, 'Approaching the Vita Nuova', in The Cambridge Companion to Dante, p. 37, and Carrai, Dante elegiaco, pp. 46-49. For a detailed analysis of number 9 in the Vita nova, see Carlo Vecce, "Ella era uno nove, cioè un miracolo" (V.N., XXIX, 3): il numero di Beatrice', in La gloriosa donna de la mente, pp. 161-180. 
scheme as well as four rhyme-words and the phrase fa tremar with Cavalcanti's Chi è questa che vèn, ch'ogn'om la mira, is similar to other Stilnovo poems celebrating the lady's powers. Staged within the Vita nova's sacred and glorifying context, these powers increase and acquire the possibility to generate love even where there's no potency for it, thereby coinciding - as several critics including De Robertis and Gorni have noticed-with a faculty that Scholastic philosophy attributes only to God. This divine faculty, however, is only present in the Vita nova and is created by the placement of the sonnet right after Amore e'l cor gentile sono una cosa. ${ }^{26}$

As mentioned above, Io mi senti' svegliar dentro a lo core in chapter XXV (15) represents a first point of arrival for this divinization of Beatrice and creates an explicit analogy between Beatrice and Christ. There is no sign of Christ in the sonnet as a free-standing rima, which is a description of the poet feeling the power of love at the arrival of Beatrice-here referred to as 'monna Bice'-accompanied by 'monna Vanna', Guido's beloved. On the other hand, in the libello the sonnet acquires a Christological meaning that aims at outlining the relationship between Dante and Cavalcanti. The prose interprets 'Primavera' in line 13 as 'prima verrà' and creates the analogy Giovanna : Beatrice $=$ John the Baptist : Amore (Christ). In the divinized context of the Vita nova, it in almost necessary for the reader to extend this analogy, explicitly indicated by the prose, to the association between Beatrice and Christ. Moreover, the whole analogy also implies John the Baptist : Christ = Cavalcanti : Dante, indicating in this way that Cavalcanti's poetry is only a preparation for Dante's poetry. ${ }^{27}$

26 By placing Ne li occhi porta after Amore e 'l cor gentile, the libello can refer to the Scholastic lexicon introduced in the 'divisione' of the former sonnet (which explained love's origin in terms of act and potency), and indicate-probably upon the suggestion of line 9, 'nasce nel core a chi parlar la sente'-that 'per lei [Beatrice] si sveglia questo Amore, e [...] non solamente si sveglia là ove dorme, ma là ove non è in potenzia, ella, mirabilmente operando, lo fa venire' (it is through her that Love is awakened and $[\ldots]$ she not only awakens him there where he sleeps, but also [...] she, miraculously working, brings hi minto existence there where he is not'; XXI 1 [12.1]). Subsequently, the whole 'divisione' continues to use Scholastic terminology to confirm and amplify the lady's divine faculties.

27 In the case Io mi senti' svegliar dentro a lo core, there are no textual variants testifying to its double existence, but the fact that in some manuscripts the sonnet is attributed to Cavalcanti, to whom it was originally addressed, has been considered by Barbi-Maggini (and subsequently by Foster-Boyde) as proof that the sonnet had circulated also before the Vita nova. In this case, the difference between the meaning of the poem read as a freestanding rima and that acquired within the libello is so significant that it seems to confirm Barbi-Maggini's hypothesis. In the 'ragione' of Io mi senti' svegliar dentro a lo core it is possible to notice a certain awareness of this décalage and almost an attempt to justify it and thereby fill it: before 'copying' the sonnet, the author warns the reader that some details explained in the 'ragione' are absent in the poem ('tacendomi certe parole le quali pareano da tacere'; XXIV 6 [15.6]). 
Thus, as was already dramatized in the previous episodes, the new meaning that the Vita nova audaciously gives to Io mi senti' svegliar dentro a lo core indicates that the author's Cavalcantian phase was merely a preparation for a new and correct way of writing that is better and superior than that of his 'first friend'. ${ }^{28}$ Moreover, the Vita nova also adds the detail that when the author wrote the sonnet, he did not know that Guido had stopped loving Giovanna, and composed the poem in the belief that Guido was still in love with her ('che ancor lo suo cuore mirasse la bieltade di questa Primavera gentile'; XXIV 6 [15.6]). In this way, the libello associates with Guido the negative theme of the mutability of desire that will be an important element of the episode of the 'donna pietosa', where it is staged as a conflict between keeping the loyalty to Beatrice after her death and yielding to the attraction towards a noble and beautiful young lady ('gentile donna giovane e bella molto'; XXXV 2 [24.2]) who had shown some compassion towards the protagonist's sorrow. ${ }^{29}$

Here I shall not explore the details of the episode of the 'donna pietosa' and shall only mention that by giving new meanings to old poems, the libello stages the protagonist's new attraction as a relapse into a Cavalcantian way of loving that is narcissistic and irrational..$^{30}$ Thus, the return to Beatrice, with which the Vita nova concludes the account of its a (u)ctor's ideal journey, also represents the final victory over the temptation of Cavalcanti's poetry. The last chapters of the Vita nova also re-state Beatrice's Christological character, which chapter XXIV had already explicitly connected with overcoming Cavalcanti, and, here as well, Beatrice's analogy with Christ is a performance undertaken by the Vita nova, achieved through the way in which it orders the poems and comments upon them.

For instance, in the penultimate sonnet of the libello, Deh, peregrini, che pensosi andate, Dante addresses some pilgrims passing through the 'città dolente', that is, Florence suffering for the death of Beatrice (XL 9 [29.9]), and tells them that while their aspects indicate that they do not know that

28 On this point, see Marti, "L'una appresso de l'altra maraviglia", pp. 141-160; Enrico Fenzi, La canzone d'amore di Guido Cavalcanti e i suoi antichi commenti, Genova 1999, pp. 23-25; Robert Durling, 'Guido Cavalcanti in the Vita nova', in Guido Cavalcanti tra i suoi lettori, pp. 177-186.

29 See Harrison, 'Approaching the Vita Nuova', pp. 42-43. On the mutability of desire in Cavalcanti's concept of love, see Enrico Fenzi, “Costanzia de la ragione" e "malvagio desiderio" (V.N., XXXIX, 2): Dante e la donna pietosa', in La gloriosa donna de la mente, pp. 209-211; and Elena Lombardi, 'The Grammar of Vision in Guido Cavalcanti', in Guido Cavalcanti tra i suoi lettori, pp. 83-92.

30 For the details, see Gragnolati, 'Trasformazioni e assenze'. 
Beatrice died, if they stopped a little and listened to some of his poems, they could not help but cry. While the sonnet only indicates that the 'pilgrims' come from afar ('da sì lontana gente' [3]), the prose goes to great lengths to explain - in a very complicated way that has often puzzled critics - that the sonnet uses the term 'peregrini' in a broad sense and what it actually meant is 'Romei', that is, the particular kind of pilgrims on their way to Rome. The prose also adds that the pilgrims addressed by the poet were going to Rome 'per vedere quella imagine benedetta la quale Iesù Cristo lasciò a noi per essemplo de la sua bellissima figura' ('to see the blessed image that Jesus Christ left us as a copy of His most beautiful face'; XL 1 [29.1]), that is, to see the Veronica, the imprint of Christ's face which Christ left on a veil during his passion on the Calvary.

The reason for these additions becomes clear in the following and last sonnet of the Vita nova, Oltre la spera che piu larga gira, which narrates that Dante's mind is able to pass through the nine material heavens, arrive at the Empyrean, and contemplate Beatrice in glory (XLI 3; [30.3]):

Quand'elli è giunto là ove disira,

vede una donna che riceve onore,

e luce sì, che per lo suo splendore

lo peregrino spirito la mira (1l. 5-8).

When it has reached the place of its desiring, / it sees a lady held in reverence / splendid in light, and through her radiance / the pilgrim spirit gazes at her being.

In 1.8 the expression 'peregrino spirito' recalls the 'peregrini' going to Rome and seeing the Veronica in the previous chapter. This is a connection noticed by several commentators of the Vita nova. For instance, Gorni writes, on the subject of 'peregrino', that 'questa qualità dello spirito congiunge strettamente questo paragrafo al precedente'. What does not seem to have been noticed is that this connection is made possible by the fact that the two sonnets are placed one after the other and, especially, that all the prose commentary about the Veronica creates a further Christological analogy recalling that encountered in I' mi seniti svegliar dentro a lo core: if there the analogy was Giovanna: John the Baptist : Cavalcanti $=$ Beatrice $:$ Christ : Dante, at the end of the Vita nova the analogy is 'peregrini' : 'spirito peregrino' = Veronica (i.e., Christ's image) : Beatrice, stressing once more the similarity between Christ and Beatrice.

This essay has indicated only some of the examples of the textual strategies that the Vita nova deploys to bring into being new poems out of the old material with which it is written. While, as we have seen at the beginning of this paper, the Vita nova's narrative represents an important step towards the constitution of a poetic ' $\mathrm{I}$ ' that presents itself as an individual and historically determined subject, the element of performance remains important in the libello. The re-writing that it creates for poems 
originally conceived of as independent rime can be considered a 'performance of the author' in two senses: not only in the sense that it is performed by a multi-faceted auctor who stages his own past as an ideal spiritual and poetic journey; but also-and this is especially what I have tried to outline-in the sense that through very same act of narrating a new author emerges in the Vita nova. It is through this performance that the libello creates a different author from the one who had originally written the rime, and replaces him. Thanks to their autobiographical and at the same time temporally-double character, the Vita nova's poems represent a special case of poetic 'workshop' or 'laboratory' that can open interesting perspectives onto the way in which Dante constructs his identity in his works. If considered from this perspective, the Vita nova is not constative but performative of its author: it does not describe or discover him, but creates him.

The author of the Vita nova is not only new with respect to the author of the rime, but by combining the authority of the auctor and a character that begins to be personalized and individualized, he also represents a new kind of author. As Albert Ascoli has recently written, it is precisely the insertion of what he calls 'personality' into the largely impersonal and ahistorical category of the medieval auctor that makes the libello one of the first instances in which an author begins to emerge who is similar to that of modern texts. ${ }^{31}$ Recalling Roland Barthes's famous essay on the 'Death of the Author', ${ }^{32}$ one could indeed speak in the Vita nova of the 'birth of the author', albeit in an initial state. But what I would like to stress is once more that the birth of this author is performative and not constative. From the perspective of my analysis, the author emerging from the Vita nova does not pre-exist his text but is performed by it.

31 'From Auctor to Author'; see also Toby Levers, 'The Image of Authorship in the Final Chapter of the Vita Nuova', in Italian Studies 57 (2002), pp. 6-10.

32 Roland Barthes, 'The Death of the Author', in Image-Music-Text, ed. by Stephen Heath, London 1977, pp. 142-148. 
